\title{
NATURAL AIRFIELD PAVEMENTS, LOAD-CARRYING CAPACITIES THERE OF, PRINCIPLES OF CONSTRUCTION AND OPERATIONAL USE
}

\section{NATURALNE NAWIERZCHNIE LOTNISK ICH NOŚNOŚĆ ORAZ WARUNKI BUDOWY I UŻYTKOWANIA}

\author{
Piotr Nita \\ Instytut Techniczny Wojsk Lotniczych \\ e-mail: piotr.nita@itwl.pl
}

\begin{abstract}
The paper has been intended to present analytically derived relationships for aircraft wheels that move through the soil medium. The analyses have been conducted for both the rigid wheel and the pneumatic whell. The most fundamental principles of constructing natural( soil) and sod/grass airfield pavements have been diccussed. Characteristic of soils typical of such pavements /surfaces have been defined. Proped are criteria for the evaluation of loadcarring capacities of such pavements. The most essential principles that goven the operational use there of follow.
\end{abstract}

Keywords: natural pavement, sod/Grass surface, load carrying capacity of the pavement, soll medium, rolling resistance of a wheel, stress in soll, depth of rut.

Streszczenie: W publikacji przedstawiono zależności teoretyczne dla kót samolotów poruszajacych się $w$ ośrodku gruntowym. Analize przeprowadzono dla koła sztywnego oraz dla kola na pneumatykach. Omówiono podstawowe zasady budowy lotniskowych nawierzchni gruntowych $i$ darniowych. Określono cechy gleb właściwych dla tego rodzaju nawierzchni. Zaproponowano również kryteria oceny nośności tych nawierzchni oraz podstawowe zasady użytkowania.

Slowa kluczowe: nawierzchnia naturalna, nawierzchnia darniowa, gleby, nośność nawierzchni, ośrodek gruntowy, opory ruchu koła, naprężenie $w$ gruncie, głębokość koleiny 
Natural airfield pavements, load-carrying capacities there of, principles of... Naturalne nawierzchnie lotnisk ich nośność oraz warunki budowy i użytkowania

\section{Wstęp}

Pod pojęciem lotniska o nawierzchni darniowej rozumie się wyznaczony obszar terenu wraz z niezbędną infrastrukturą techniczną przystosowany do wykonywania operacji lotniczych. Obecnie nawierzchnie darniowe występują przede wszystkim na lotniskach o niższej klasie technicznej. Na lotniskach, mających wyższą klasę techniczną, występują głównie jako boczne i często jako czołowe pasy bezpieczeństwa.

Ten rodzaj nawierzchni dominuje na lotniskach sportowych, które charakteryzują się mniejszym ruchem i obciążeniami. Wymagania dla tego rodzaju nawierzchni pod względem nośności są jednak bardzo wysokie. Nośność nawierzchni darniowej musi być taka, by zapewniała możliwość wykonywania operacji lotniczych, przy zmieniającym się stanie nawilgocenia gruntów. Warunki takie może spełnić darń wytworzona i utrzymana na odpowiedniej glebie, charakteryzująca się właściwą zwartością i odpornością na różnorodne obciążenia mechaniczne. Dla tego rodzaju nawierzchni, znaczenie ma również stan porostu roślin, który powinien być intensywny dobrze i równo pokrywający glebę. Nawierzchnia darniowa jest w swojej istocie ulepszonym rodzajem nawierzchni gruntowej.

\section{Podstawowe pojęcia dotyczące nawierzchni darniowych oraz zasady lokalizacji tych obiektów}

Lotniskowa nawierzchnia darniowa jest nawierzchnia gruntowa, pokryta warstwą rozwiniętej roślinności trawiastej i przystosowanej do wykonywania operacji lotniczych. Uważa się, ze obciążenie na goleń główną samolotu nie powinno dla tej nawierzchni przekraczać $100,00 \mathrm{kN}$.

Darń jest zwartą pokrywą roślinną, stanowiąca wierzchnią warstwę gleby wzmocnionej rozwiniętym systemem korzeniowym. Grubość tej warstwy wynosi zwykle od 10 do $18 \mathrm{~cm}$. Gleba jest wierzchnią warstwą gruntu, w której rozwija się roślinność, w której zachodzą procesy fizyko-chemiczne, związane z pożądanym rozwojem tej roślinności. Darń jest charakterystycznym pokryciem łąk i pastwisk.

Humus (próchnica) jest bezpostaciowym, naturalnym produktem mikrobiologicznego rozkładu substancji organicznych.

Nośność nawierzchni darniowej wyraża sumaryczny opór, który stawia rozwinięty system korzeniowy roślin i zawartych $\mathrm{w}$ nim cząstek gruntu obciążeniom pochodzącym od ciężaru samolotu, będącego w ruchu lub w stanie spoczynku.

Przy wyborze terenu pod lotnisko o nawierzchni darniowej, należy mieć na uwadze to, że obowiązują wszystkie ustalenia i zasady, jak dla lotnisk o nawierzchniach sztucznych. Zasadniczym czynnikiem jest jednak rodzaj gleby. Rodzaj gleby, pomimo spełnienia szeregu innych wymaganych warunków, przesądzić może o negatywnym charakterze i wartości obranego terenu pod przyszłe lotnisko, na którym miałby być zastosowany ten rodzaj nawierzchni. Powstanie gleby wiąże się z szeregiem procesów erozyjnych skał spowodowanych wpływem zmian temperatury, wód opadowych i innych czynników. Pod względem pochodzenia rozróżnia się gleby pierwotne, tj. takie które powstały z rozkładu skał rodzimych - 
miejscowych, w podłożu ich znajduje się nie zwietrzała skała macierzysta, oraz gleby naniesione, tj. takie, które leżą na obcym sobie - pod względem pochodzenia podłożu, które znalazły się tam $\mathrm{w}$ wyniku naniesienia przez wiatry, lodowiec i inne czynniki. Gleby mieszane to przede wszystkim gleby pierwotne w składzie, których znajdują się gleby naniesione. W zależności od przebiegu procesów zachodzących $\mathrm{w}$ glebach na przestrzeni czasu, powstają rożne ich rodzaje. Pod względem własności mechanicznych gleby podzielić można na:

- utwory kamieniste - zawierające przeważające ilości kamieni,

- utwory żwirowe - zawierające w swoim składzie znaczne ilości żwiru o różnym uziarnieniu oraz od 0 do $20 \%$ cząstek spławialnych,

- piaski, w których przeważają frakcje piaskowe tj. od 0 - $4.0 \mathrm{~mm}$, a ilość cząstek spławialnych. wynosi również do $20 \%$,

- utwory pyłowe - zawierają w swoim składzie ponad 40 \% części pyłowych i ponad $45 \%$ części spławialnych,

- gliny - są utworami różnoziarnistymi i w zależności od rodzaju zawierają pewną ilość cząstek spławialnych, głównie od 20 do $45 \%$,

- iły - to utwory, które zawierają ponad $45 \%$ części spławialnych, części pyłowe oraz domieszki piasku, i wyjątkowo ziarna grube.

Częściami spławialnymi w rozumieniu tej klasyfikacji są:

- ił pyłowy, którego średnica cząstek wynosi od 0,01 do 0,001 mm;

- ił koloidalny o średnicy cząstek mniejszej od $0,001 \mathrm{~mm}$.

W tablicy 1 zamieszczono rodzaje gleb, które występują na terenie naszego kraju, określono również ich przydatność do budowy lotnisk o nawierzchniach naturalnych.

Niezależnie od własności mechanicznych gleby, ważne są również inne czynniki i związki chemiczne tj. takie, które wchodzą w jej skład, należą do nich: węglan wapnia, próchnica, woda, powietrze oraz różne rodzaje bakterii. Czynniki te, wchodzą w skład gleby i umożliwiają życie roślin stanowiących osnowę nawierzchni darniowej. Wymienione składniki gleby znajdują się we wszystkich jej rodzajach, różnice występują tylko w ilości i sposobie ich zmieszania. Każdy z tych składników gleby ma do spełnienia ważne funkcje, bez której uzyskanie pożądanej gleby dla celów budowy lotniska o nawierzchni darniowej byłoby bardzo trudne. Ważny jest całokształt gospodarki wodnej w glebie, który uzależniony jest przede wszystkim od klimatu charakterystycznego dla danej okolicy. Istotna dla właściwego poziomu technicznego i pożądanego poziomu utrzymania nawierzchni darniowej jest gospodarka wodna w tym obszarze. Najważniejsze w niej są opady atmosferyczne w ciągu całego roku i w okresie wegetacyjnym. O stanie technicznym nawierzchni darniowej w dużej mierze decyduje ilość opadów. Minimalna ilość opadów, przy której bez sztucznego zraszania, możliwe jest utrzymanie trawiastej nawierzchni lotniska w odpowiednim stanie technicznym.

Stan techniczny gleb przeznaczonych pod ewentualne lotnisko zależy od: rodzaju gleby, jej przepuszczalności, struktury i pojemności wodnej oraz położenia i poziomu zwierciadła wody gruntowej. 
Natural airfield pavements, load-carrying capacities there of, principles of... Naturalne nawierzchnie lotnisk ich nośność oraz warunki budowy i użytkowania

Tablica 1. Rodzaje gleb występujących na terenie kraju

\begin{tabular}{|c|c|c|c|}
\hline Rodzaj gleby & Grupy gleb & \multicolumn{2}{|c|}{ Odmiany gleb } \\
\hline \multirow{13}{*}{ A. Gleby krzemianowe } & \multirow{3}{*}{ I grupa piasków } & 1. gleby żwirowe & \\
\hline & & 2. gleby piaszczyste & $\begin{array}{l}\text { a) wydmy } \\
\text { b) piaski mokre } \\
\text { c) pisaki suche } \\
\text { d) szczerki lekkie }\end{array}$ \\
\hline & & 3. piaski gliniaste & \\
\hline & & 1. piaski kwarcowe & \\
\hline & $\begin{array}{l}\text { II grupa bielic - gleb } \\
\text { krzemionkowych }\end{array}$ & 2. bielice właściwe & $\begin{array}{l}\text { a) na żwirze } \\
\text { b) na glinie } \\
\text { c) na piasku } \\
\text { d) na mocnej glinie } \\
\text { e) na wapieniu }\end{array}$ \\
\hline & & 3. lessy bielice & \\
\hline & & $\begin{array}{l}\text { 1. lessy głębokie } \\
\text { (właściwe) }\end{array}$ & \\
\hline & III grupa lessów & 2. lessy płytkie & $\begin{array}{l}\text { a) na pisaku lodowcowym } \\
\text { b) na wapieniu } \\
\text { c) na glinie piaszczystej } \\
\text { d) na glinie thustej }\end{array}$ \\
\hline & & 3. bielica - less & \\
\hline & & 1. mady chude & \\
\hline & IV mady & 2. mady thuste & \\
\hline & V Jly & 1. iły & $\begin{array}{l}\text { a) piaskowce karpackie } \\
\text { b) iły właściwe }\end{array}$ \\
\hline & V 11y & 2. gliny & $\begin{array}{l}\text { a) lodowcowe } \\
\text { b) piaskowcowe }\end{array}$ \\
\hline & & 1. redzina (borowina) & $\begin{array}{l}\text { a) czarna } \\
\text { b) biała } \\
\text { c) żółta }\end{array}$ \\
\hline & & 2. redzina jurska & \\
\hline & I grupa węglanowa & 3. redzina kredowa & \\
\hline B. Gleby wapniowe & & 4. redzina laberytowa & \\
\hline & & 5. redzina ziarnista & \\
\hline & & 6. redzina marmurowa & \\
\hline & & 7. redzina dolomitowa & \\
\hline & II grupa siarczanowa & Redzina gipsowa & $\begin{array}{l}\text { a) lekka } \\
\text { b) ciężka }\end{array}$ \\
\hline & & $\begin{array}{l}\text { 1. czarnoziemy } \\
\text { właściwe stepowe }\end{array}$ & \\
\hline & I. grupa gleb stepowych & $\begin{array}{l}\text { 2. czarnoziemy } \\
\text { zdegradowane }\end{array}$ & \\
\hline$C$ Gleby nróchnicowe & & 3. bielico-czarnoziemy & \\
\hline C. Gleby procnnicowe & & 1. czarne ziemie & $\begin{array}{l}\text { (sochaczewska, błońska, } \\
\text { kujawska) }\end{array}$ \\
\hline & 11. grupa czarnych ziem & 2. cepuch & \\
\hline & & 3. mursz & \\
\hline & & 4. torf & \\
\hline
\end{tabular}


Przy opadach rocznych wynoszących ponad $650 \mathrm{~mm}$ możliwe jest utrzymanie darni w dobrym stanie nawet wówczas, gdy poziom wody gruntowej jest bardzo niski. Ewentualne ograniczenia dotyczą tylko zalegających grubych piasków, które z natury swojej są bardzo przepuszczalne. Własnością gleby, która zapewnia odpowiednią jakość darni jest jej żyzność. Stopień żyzności gleby określa jej zdolność do jednoczesnego zaopatrywania roślin w wodę i łatwo rozpuszczalne składniki pokarmowe, które tym samym są łatwo przyswajalne przez rośliny. Pożądana jest gleba gruzełkowata lub inaczej strukturalna. Jest to ta właściwość gleby, w której wszystkie mineralne cząstki składowe nie pozostają rozproszone lecz są zlepione w gruzełki o średnicy od 1,0 do $10,0 \mathrm{~mm}$. Gleby strukturalne są najbardziej żyzne z uwagi na swoją właściwość pochłaniania wody i trwałego jej magazynowania.

Z rocznej sumy opadów około $85 \%$ zostaje zaabsorbowanych przez ten właśnie rodzaj gleby. Uzyskanie i utrzymanie, strukturalnej gleby na darniowej nawierzchni lotniska jest bardzo pożądanym i racjonalnym działaniem. Na terenie kraju występuje bardzo duże zróżnicowanie gleb, jest to wynikiem: odmiennych warunków hydrograficznych i klimatycznych oraz dużej ilości formacji geologicznych. Każda z wymienionych formacji geologicznych ma swoje cechy charakterystyczne, które dają się łatwo rozróżnić. Te charakterystyczne cechy, pozwalają na ich klasyfikację pod kątem ich przydatności do budowy i późniejszego utrzymania nawierzchni. Dla lotnisk komunikacyjnych i sportowych najodpowiedniejszą jest gleba średnio zwięzła, bogata w roślinne składniki pokarmowe. Pożądane jest, by poziom wody gruntowej w okresie pełnego rozwoju traw (początek czerwca) znajdował się na głębokości $70-80 \mathrm{~cm}$ od powierzchni terenu - dla gleb zwięzłych, dla gleb bardziej przepuszczalnych poziom wody gruntowej winien kształtować się na głębokości 60-70 cm. Nawierzchnie lotniskowe przygotowane na takich glebach są stosunkowo łatwo pokrywające się darniną. Zadarnienie jest latwe $\mathrm{w}$ utrzymaniu, a prace konserwacyjne są stosunkowo proste i mało absorbujące. Nawet wówczas gdy zadarnienie nie zostało wykonane, nawierzchnie takie, $\mathrm{z}$ uwagi na własne strukturalne możliwości, mają naturalną odporność na przenoszenie obciążeń pochodzących od kół samolotu.

Własności tej gleby z uwagi na odpowiednią strukturę nie podlegają intensywnym wahaniom nawet $w$ wyniku nadmiernego nawilgocenia czy też przesuszenia. Do zalecanych gleb, które mogą być wykorzystane w szerokim zakresie do budowy zaliczyć można następujące ich rodzaje: piaski gliniaste, gleby krzemionkowe z ich odmianami tj. piaskach, glinach piaszczystych, mocnej glinie, które w tablicy 1 oznaczono jako: A-I3; II2, b, c, d; III2a,b i 3 oraz C I 1,2,3.

Mniej przydatne do budowy nawierzchni lotniskowych darniowych będą gleby cięższe, mniej przepuszczalne i przewiewne, których konsystencja i wytrzymałość zmienia się znacznie $\mathrm{W}$ zależności od okresowego nawilgocenia gruntu. Nawierzchnia trawiasta jest stosunkowo łatwa do założenia na tych glebach, trudna jest w okresie późniejszym do utrzymania i konserwacji. 
Natural airfield pavements, load-carrying capacities there of, principles of... Naturalne nawierzchnie lotnisk ich nośność oraz warunki budowy i użytkowania

Nośność takiego gruntu jest zależna od stopnia nawilgocenia, a nawet najlepiej rozwinięta i utrzymana darń nie jest w stanie znacząco poprawić jej nośności. Do tych gleb mniej nadających się do budowy nawierzchni lotnisk zaliczyć można: lessy płytkie i głębokie zalegające na glinach ciężkich i wapieniach. Lotnisk nie należy lokalizować na glebach takich jak, ciężkie tłuste gliny, iły, torfy i płytkie rędziny na podłożu wapiennym. Dla każdego z tych wymienionych rodzajów gruntu znajdują się uzasadnione przeciwwskazania do ich wykorzystania w celu budowy lotniska. Do gleb, które należy wykluczyć przy ewentualnej lokalizacji lotniska, zaliczyć należy następujące: gleby żwirowe i drobno piaszczyste, płytkie rędziny w tym kredowe, laterytowe i torfy.

Ogólnie stwierdzić można, że na glebach zawierających 40 - $50 \%$ części spławialnych nie należy budować lotnisk komunikacyjnych i sportowych.

Do budowy lotnisk zaleca się wybierać teren, dla którego oprócz spełnienia ogólnych warunków lokalizacji lotniska grunt winien charakteryzować się 20 - $30 \%$ ilością części spławialnych. Są to gleby zwane potocznie jako piaszczystogliniaste, gliniasto-piaszczyste i szczerkowate.

Decyzja o lokalizacji lotniska o nawierzchni darniowej musi być poprzedzona odpowiednimi badaniami geotechnicznymi, które rozstrzygną o potrzebie innych przedsięwzięć, takich jak np. drenaż lotniska lub odwodnienie. Drenaż lotniska ma przede wszystkim na celu poprawienie fizycznych własności gruntów i zabezpieczenie przed ujemnymi wpływami atmosferycznymi tego obszaru. Obniża on zwierciadło wody gruntowej do poziomu wymaganego dla zapewnienia bezpieczeństwa ruchu lotniczego oraz szybkiego odprowadzenia z gleby nadmiaru wód opadowych dla zapewnienia ciągłości tego ruchu. Wykonanie drenażu na terenie lotniska o nawierzchni darniowej niezbędne jest wówczas, gdy:

1) zwierciadło wody gruntowej $\mathrm{w}$ porze mokrej osiąga poziom $50 \mathrm{~cm}$ na terenach lotnisk, głównie sportowych i $80 \mathrm{~cm}$ na terenach lotnisk komunikacyjnych;

2) na terenie pola wzlotów, stwierdzono gniazda lub żyły wodne;

3) charakter i rodzaj gleby obranego terenu i przeznaczonego na pole wzlotów nie jest jednolity, $w$ związku $\mathrm{z}$ tym mogą występować znaczne różnice w zachowaniu się pewnych partii różnorodnej gleby, przy zmianie jej wilgotności.

Przeprowadzenie drenażu jest celowe, korzystne i opłacalne na glebach zwięzłych, gliniastych i trudno przepuszczalnych, w których zawartość cząstek spławialnych wynosi 40 - $50 \%$. Wymagają one drenowania bez względu na poziom wód gruntowych dla przyspieszenia ich obsychania i stworzenia lepszych warunków dla wzrostu rozwoju roślin porastających nawierzchni lotniska.

Przeprowadzenie drenażu może być zbędne na glebach lżejszych, gliniastopiaszczystych i łatwo przepuszczalnych. Bardzo dobry stan darni lotniskowej o maksymalnej nośności jest czynnikiem utrudniającym szybkie przesiąkanie wody opadowej w głąb gruntu. Silnie rozwinięty system korzeni roślin tworzy pewnego rodzaju warstwę izolującą. Dlatego na dobrze rozwiniętej darni czasami zaobserwować można zjawisko utrzymywania się wody przez krótki czas nawet na darni leżącej na gruncie przepuszczalnym. Próba poprawy tego stanu poprzez wybudowanie bardziej sprawnego systemu drenarskiego byłaby bardzo kosztownym błędem. 


\section{Nośność nawierzchni darniowych}

Z punktu widzenia techniki lotniskowej nawierzchnią darniową jest wykształcony typ gleby o rozwiniętej roślinności trawiastej i przystosowanej do startów i lądowań samolotów dzięki odpowiednim zabiegom agrotechnicznym i technicznym. Nawierzchnia darniowa jest ulepszonym typem nawierzchni gruntowej, która zmniejsza nawilgocenie gruntu, zwiększa jego wytrzymałość oraz przedłuża czas eksploatacji. Na nawierzchni darniowej możliwe jest eksploatowanie samolotów, których obciążenie na goleń nie przekracza $100 \mathrm{kN}$. Nośność nawierzchni dla obecnie eksploatowanych lekkich samolotów powinna być nie mniejsza niż $0,8-1,0 \mathrm{MPa}$ według oceny wytrzymałości $\sigma$ sondą udarową (patrz wzór nr 2). Uważa się również, że dopuszczalna głębokość koleiny po przejeździe samolotu na lotnisku o nawierzchni darniowej, może wynosić maksimum $6 \mathrm{~cm}$. Nawierzchnia darniowa daje możliwość zwielokrotnienia około 3-5 razy nacisków kół w porównaniu z nawierzchnią gruntową bez darni.

Według [1] zależności pomiędzy wytrzymałością gruntu i jego wilgotnością w \% dla nawierzchni gruntowej $\mathrm{i}$ nawierzchni trawiastej przebiega tak, jak przedstawiono na rys. 1

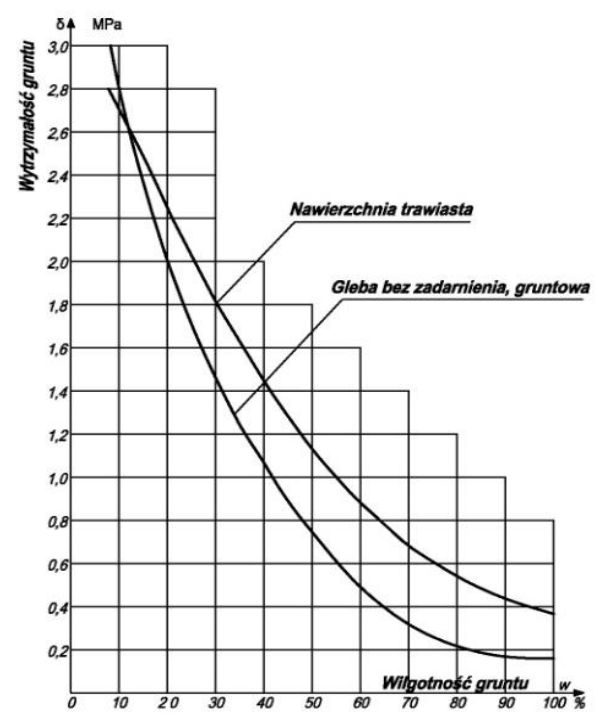

Rys.1 Zależność pomiędzy wytrzymałościa $\sigma$ nawierzchni gruntowej, darniowej a wilgotnościa

Metody określania nośności nawierzchni darniowej i gruntowej są identyczne. Uważa się jednak, że jedną z częściej stosowanych i najbliższych rzeczywistości jest metoda FAA (Federal Aviation Agency). Jest to metoda doświadczalna, w której wykorzystuje się dokładną klasyfikację warunków gruntowo-wodnych oraz obciążenie nawierzchni pojedynczą jednokołową golenią samolotu. 
Natural airfield pavements, load-carrying capacities there of, principles of... Naturalne nawierzchnie lotnisk ich nośność oraz warunki budowy i użytkowania

Zasadę tej klasyfikacji według metody FAA przedstawiono na rys. 2

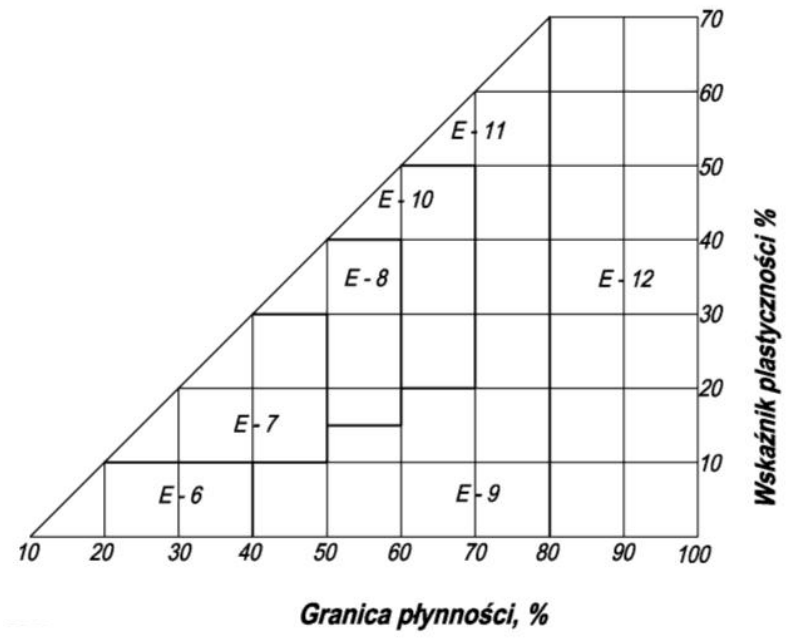

Rys. 2 Klasyfikacja gruntów drobnoziarnistych wedlug FAA

Podstawą klasyfikacji gruntów według tej metody jest analiza uziarnienia, granica płynności i wskaźnik plastyczności gruntu. Zasadnicze parametry klasyfikacji gruntów spoistych i niespoistych przedstawiono w tabeli 2.

Założenia, które przyjmuje się w celu określenia warstwy gruntu jest jej zagęszczenie wynoszące zwykle około $90 \%$ odniesione w stosunku do zagęszczenia otrzymanego według zmodyfikowanej metody Proctora. Dla metody normalnej, zagęszczenie winno wynosić powyżej 95\%.

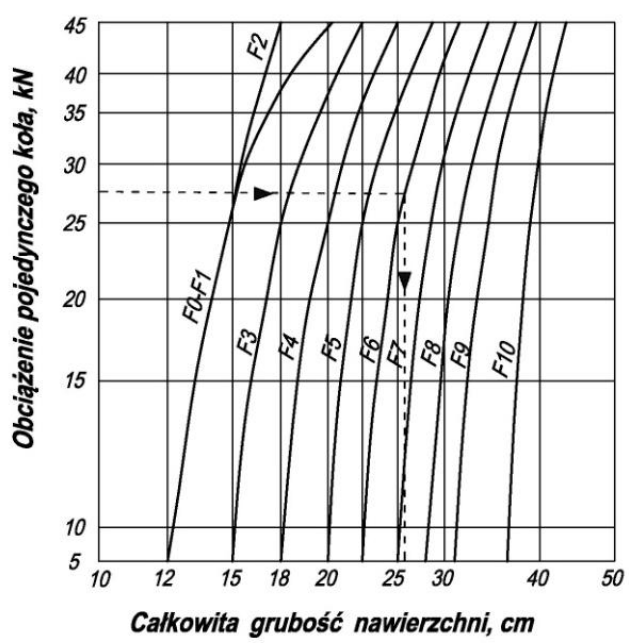

Rys.3 Wykres do wymiarowania nawierzchni gruntowych i podatnych wg. FAA w zależności od obciążenia koła i klasy podłoża. 
Wykorzystując ustalenia zamieszczone w tabeli 2, określa się grubość nawierzchni gruntowej z mieszanki optymalnej według zasad przedstawionych na rys. 3, dalej zaś dobiera się wymagana grubość darni wg tablicy 2 . Oznaczenia literą $F$ na rysunku 3 dotyczy grubości podbudowy.

Tablica 2. Klasyfikacja gruntów do projektowania podatnych nawierzchni lotniskowych metoda FAA

\begin{tabular}{|c|c|c|c|c|c|c|c|c|c|c|}
\hline \multirow{4}{*}{ 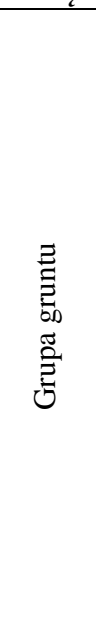 } & \multicolumn{4}{|c|}{ Uziarnienie $\mathrm{w} \%$} & \multirow{4}{*}{ 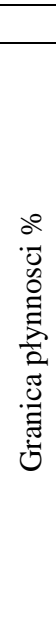 } & \multirow{4}{*}{ 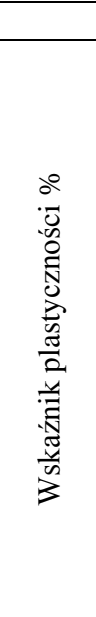 } & \multicolumn{4}{|c|}{ Klasa podloża } \\
\hline & \multirow{3}{*}{ 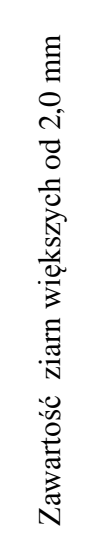 } & \multirow{3}{*}{ 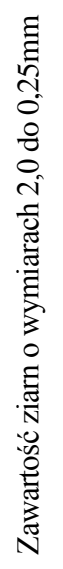 } & \multirow{3}{*}{ 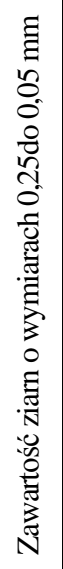 } & \multirow{3}{*}{ 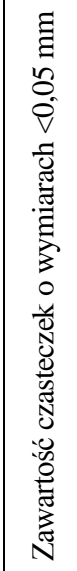 } & & & \multirow{2}{*}{\multicolumn{2}{|c|}{ dobre }} & \multirow{2}{*}{\multicolumn{2}{|c|}{ nienie }} \\
\hline & & & & & & & & & & \\
\hline & & & & & & & 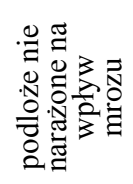 & 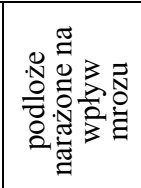 & 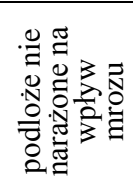 & 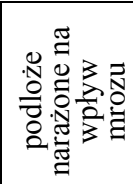 \\
\hline$E-1$ & $0-45$ & 40 & 60 & 15 & 25 & 6 & $\mathrm{Fa}$ & $\mathrm{Fa}$ & $\mathrm{Fa}$ & $\mathrm{Fa}$ \\
\hline$E-2$ & $0-45$ & 15 & 85 & 25 & 25 & 6 & $\mathrm{Fa}$ & $\mathrm{Fa}$ & $\mathrm{F}_{1}$ & $\mathrm{~F}_{2}$ \\
\hline $\mathrm{E}-3$ & $0-45$ & & & 25 & 25 & 6 & $\mathrm{~F}_{1}$ & $\mathrm{~F}_{1}$ & $\mathrm{~F}_{2}$ & $\mathrm{~F}_{2}$ \\
\hline $\mathrm{E}-4$ & $0-45$ & & & 35 & 35 & 10 & $\mathrm{~F}_{1}$ & $\mathrm{~F}_{1}$ & $\mathrm{~F}_{2}$ & $\mathrm{~F}_{3}$ \\
\hline$E-5$ & $0-45$ & & & 45 & 40 & 15 & $\mathrm{~F}_{1}$ & $\mathrm{~F}_{2}$ & $\mathrm{~F}_{3}$ & $\mathrm{~F}_{4}$ \\
\hline$E-6$ & $0-55$ & & & 45 & 40 & 10 & $\mathrm{~F}_{2}$ & $\mathrm{~F}_{3}$ & $\mathrm{~F}_{4}$ & $\mathrm{~F}_{5}$ \\
\hline $\mathrm{E}-7$ & $0-55$ & & & 45 & 50 & $10-30$ & $\mathrm{~F}_{3}$ & $\mathrm{~F}_{4}$ & $\mathrm{~F}_{5}$ & $\mathrm{~F}_{6}$ \\
\hline $\mathrm{E}-8$ & $0-55$ & & & 45 & 60 & $15-40$ & $\mathrm{~F}_{4}$ & $\mathrm{~F}_{5}$ & $\mathrm{~F}_{6}$ & $\mathrm{~F}_{7}$ \\
\hline$E-9$ & $0-55$ & & & 45 & 40 & 30 & $\mathrm{~F}_{5}$ & $\mathrm{~F}_{6}$ & $\mathrm{~F}_{7}$ & $\mathrm{~F}_{8}$ \\
\hline $\mathrm{E}-10$ & $0-55$ & & & 45 & 70 & $20-50$ & $\mathrm{~F}_{5}$ & $\mathrm{~F}_{6}$ & $\mathrm{~F}_{7}$ & $\mathrm{~F}_{8}$ \\
\hline $\mathrm{E}-11$ & $0-55$ & & & 45 & 80 & 30 & $\mathrm{~F}_{6}$ & $\mathrm{~F}_{7}$ & $\mathrm{~F}_{8}$ & $\mathrm{~F}_{9}$ \\
\hline $\mathrm{E}-12$ & $0-55$ & & & 45 & 80 & - & $\mathrm{F}_{7}$ & $\mathrm{~F}_{8}$ & $\mathrm{~F}_{9}$ & $\mathrm{~F}_{10}$ \\
\hline$E-13$ & & & & & & in & - niep & atne jal & odloze & \\
\hline
\end{tabular}

Klasyfikacja gruntów E określa własności gruntu w połączeniu z warunkami miejscowymi hydro - geologicznymi.

Tablica 3. Grubość nawierzchni darniowej w zależności od E

\begin{tabular}{|c|c|}
\hline Grupa gruntu & Wymagana grubosc darni $\mathrm{w} \mathrm{cm}$ \\
\hline $\mathrm{E}_{1}$ do $\mathrm{E}_{5}$ & 10 do 15 \\
$\mathrm{E}_{6}$ do $\mathrm{E}_{7}$ & co najwyzej do 15 \\
$\mathrm{E}_{8}$ do $\mathrm{E}_{12}$ & 15 do 25 \\
$\mathrm{E}_{13}$ & nieprzydatne \\
\hline
\end{tabular}


Natural airfield pavements, load-carrying capacities there of, principles of... Naturalne nawierzchnie lotnisk ich nośność oraz warunki budowy i użytkowania

\section{Metody określania charakterystyk ruchu kól samolotów poruszających się w niejednorodnym ośrodku gruntowym.}

Koło samolotu lub pojazdu transportowego spełnia podstawową zasadę ruchu środków transportu po nawierzchni gruntowej. Dlatego poznanie mechaniki ruchu pojazdu w ośrodku gruntowym jest bardzo ważne. Jednym z podstawowych celów poznania wzajemnego oddziaływania pojazdu i ośrodka gruntowego okazuje się zapewnienie i pewność metody określania siły ciągu lub napędu oraz oporów ruchu w różnorodnych postaciach.

\section{Opory ruchu sztywnego kola.}

Chociaż pneumatyczne koła dawno już zastąpiły sztywne koła poruszające się w ośrodku gruntowym. To jednak mechanika sztywnych kół związana $\mathrm{z}$ ruchem w tym ośrodku wciąż pozostaje interesująca przede wszystkim dlatego, że pneumatyczne koła przedstawiają sobą podobną sprężystą obręcz nawet przy niskim ciśnieniu powietrza. Jedyną z dobrze znanych metod określania oporów ruchu sztywnego koła jest metoda przedstawiona przez [7].Opracowując to zagadnienie przedstawiono, że reakcja gruntu we wszystkich punktach jest radialnym naprężeniem i równa jest normalnemu ciśnieniu pod horyzontalną płaszczyzną na tej głębokości. Równanie równowagi określonego sztywnego koła może być przedstawione w następującej postaci:

$$
R_{c}=b \int_{0}^{\theta_{0}} \sigma r \sin \theta d \theta
$$

Pionowe obciążenie na grunt przekazywane przez grunt przedstawia zależność

$$
W=b \int_{0}^{\theta_{o}} \sigma r \cos \theta d \theta
$$

Schematyczny rozkład sił na układ sztywne koło podłoże gruntowe przedstawia rys. 4 .

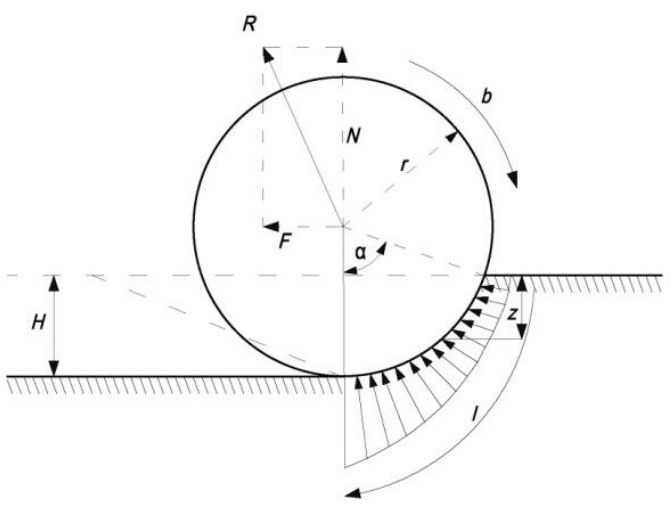

Rys.4 Uproszczony model oddziaływania koła z ośrodkiem gruntowym 
Tak jak zaznaczono naprężenie $\sigma$ działające na obwodzie koła, równe jest normalnemu ciśnieniu p działającemu pod powierzchnią na określonej głębokości $\mathrm{z}$, wówczas $\mathrm{pdz}=\sigma \mathrm{r} \sin \theta \mathrm{d} \theta$ oraz $\mathrm{pdx}=\sigma \mathrm{x} \cos \theta \mathrm{d} \theta$. Wykorzystując związki między ciśnieniem i osiadaniem, wyznaczono je z zależność:

$$
\mathrm{p}=(\mathrm{kc} / \mathrm{b}+\mathrm{k} \varphi) \mathrm{zn}
$$

gdzie : $\mathrm{n} \quad-$ wykładnik wielkości odkształcenia

b - najmniejszy wymiar płaszczyzny obciążenia, (lub szerokość prostokątnej płyty)

$\mathrm{kc}$ oraz $\mathrm{k} \varphi$ - moduł $\mathrm{i}$ tarcie przy odpowiedniej wielkości odkształceniu ośrodka

Przekształcając równanie wyznaczające Rc otrzymamy

$$
R_{c}=b \int_{0}^{z_{o}}\left(\frac{k_{c}}{b}+k_{\varphi}\right) z^{n} d z=b\left[\frac{z_{o}{ }^{n+1}}{n+1}\right]\left(\frac{k_{c}}{b}+k_{\varphi}\right)
$$

Wyznaczenie Rc wg zależności (4) jest równoważne pionowemu oddziaływaniu przeliczonemu na jednostkę długości przy zagłębieniu płyty o szerokości b w gruncie na głębokość $z_{o}$. Dopuszczalny rozkład ciśnienia oznacza, że opory ruchu sztywnego koła są następstwem pionowego obciążenia powodującego powstanie koleiny o głębokości zo. Określone w ten sposób opory ruchu utożsamiać można z oporami zagęszczonego lub pozostającego w luźnym stanie ośrodka. Wykorzystując zależność (4) dla obliczenia oporów ośrodka, wyrazić można osiadanie warstwy gruntu $z_{o}$ przez parametry koła i właściwości gruntu z zależności (2) wówczas pionowe oba na grunt można przedstawić wg zależności (5):

$$
W=-b \int_{0}^{Z_{o}} p d x=-b \int_{0}^{Z_{o}}\left(\frac{k_{c}}{b}+k_{\varphi}\right) z^{n} d x
$$

Z warunków geometrycznych wynikających z rys.4. można wnioskować, że

$$
\begin{gathered}
x^{2}=\left[D-\left(z_{0}-z\right)\right]\left(z_{0}-z\right) \\
x^{2}=D\left(z_{0}-z\right)
\end{gathered}
$$

gdzie: D - średnica koła odpowiednia dla niewielkich osiadań oraz

$$
2 x d x=-D d z
$$

Podstawiając zależność (7) do (4) otrzymamy

$$
W=b\left(\frac{k_{c}}{b}+k_{\phi}\right) \int_{0}^{Z_{o}} \frac{z^{n} \sqrt{D}}{2 \sqrt{z_{o}-z}} d z
$$

Zakładając $z_{o}-z=\mathrm{t}^{2}$ wówczas $\mathrm{dz}=-2 \mathrm{t} \mathrm{dt}$ 
Natural airfield pavements, load-carrying capacities there of, principles of... Naturalne nawierzchnie lotnisk ich nośność oraz warunki budowy i użytkowania

Rozwiązując wyrażenie $\left(\mathrm{z}_{\mathrm{o}}-\mathrm{t}^{2}\right)^{\mathrm{n}}$ i uwzględniając tylko dwa pierwsze człony szeregu

otrzymujemy $\left(\mathrm{z}_{\mathrm{o}}^{\mathrm{n}}-\mathrm{nz_{ \textrm {o } }}{ }^{\mathrm{n}-1} \mathrm{t}^{2}+\right.$ .) otrzymamy zależność

$$
W=\frac{b\left(\frac{k_{c}}{b}+k_{\varphi}\right) \sqrt{z_{o} D}}{3} z_{o}^{n}(3-n)
$$

Wykorzystując powyższe otrzymamy

$$
z_{o}^{(2 n+1) / 2}=\frac{3 W}{b\left(\frac{k_{c}}{b}+k_{\varphi}\right) \sqrt{D}(3-n)}
$$

lub inną postać $\mathrm{z}_{\mathrm{o}}$

$$
z_{o}=\left[\frac{3 W}{b(3-n)\left(\frac{k_{c}}{b}+k_{\varphi}\right) \sqrt{D}}\right]^{\frac{2}{(2 n+1)}}
$$

Wykorzystując zależność n i wyrażenie na Rc oraz zależność (3) otrzymamy ostateczną postać Rc oporu ruchu w odpowiednio zagęszczonym ośrodku gruntowym.

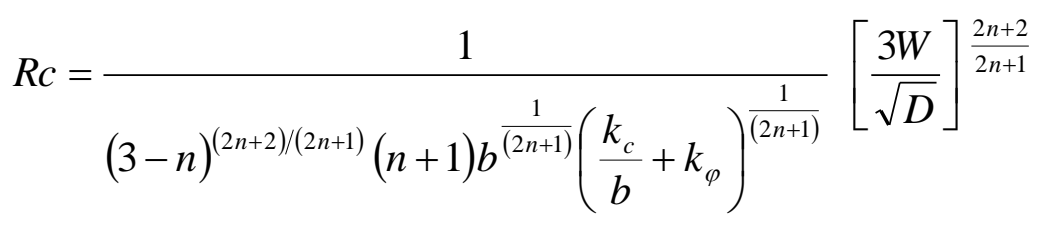

Z zależności tej wynika, że dla obniżenia oporów ruchu bardziej efektywnym jest zwiększenie średnicy koła $D$, niż jego szerokości. Średnica D wchodzi w równanie w stopniu wyższym, niż b. W opracowaniu[7] wykazano, że możliwe do przyjęcia średnie osiadanie tj. przy $\mathrm{z}_{\mathrm{o}}=\mathrm{D} / 6$ może być otrzymane przy wykorzystaniu równania (12) i to, że większa średnica i mniejsze osiadanie, tym będzie większe punktowe występowanie tego zjawiska. Autor [7] wykazał, że osiadanie wyznaczone z zależności (12) dla kół o średnicy mniejszej niż $50 \mathrm{~cm}$ sprawia, że ruch jest mniejszy, niż określone zagłębienie wyznaczone wg równania (11), w którym rozpatrywano grunt piaszczysty.

Eksperymentalne badania wykazują, że działający rozkład normalnego ciśnienia pod sztywnym kołem różni się nieco od rozkładu ciśnienia, które przedstawiono w pierwszym wywodzie. W zgodności z tymi przedstawionymi zależnościami, maksymalne normalne ciśnienie będzie występować w najniższym punkcie kontaktu gdzie osiadanie jest maksymalne. 
Rezultaty doświadczeń mówią o tym, że normalne ciśnienie na maksymalną wartość w tzw. martwym punkcie miejsce jego występowania zależy od ruchu koła wg własnej osi tj. bez występowania zjawiska przemieszczania się tego koła. Równanie (12) pozwala wyznaczyć opory ruchu dla gruntów o równomiernym uziarnieniu i gruntów spoistych do gruntów gliniastych opracowano inną teorię [8] określenia oporów w ośrodku skomprymowanym tak, że reakcja gruntu ukierunkowana jest wg promienia, w następstwie tego zrównoważone opory ośrodka przy pionowym obciążeniu zanikają na ukształtowanie się koleiny na jednostkę długości przemieszczenia. Jednak wg tej teorii dopuszcza się, że normalne lub radialne naprężenie jest stałe dla wszystkich powierzchni kontaktu $\mathrm{i}$ równe jest teoretycznej nośności idealnie równej powierzchni tj. $\sigma=5,7 \mathrm{c}$. Założenie to można rozpatrywać jako szczególny przypadek równania przedstawionego przez [7] tj. zależność osiadania $\mathrm{i}$ ciśnienia przy $\mathrm{n}=0$ $\mathrm{i}(\mathrm{kc} / \mathrm{b}+\mathrm{k} \varphi)=5,7 \mathrm{c}$. Wykorzystując te zależność w równaniu (11) i (12), otrzymuje się wyrażenie na osiadanie (zagłębienie) i opory ruchu dla sztywnego koła w następującej postaci:

$$
z_{o}=\frac{W^{2}}{(5,7 c)^{2} \frac{b^{2}}{D}} \quad \text { zaś Rc } \quad R c=\frac{W^{2}}{5,7 c b D}
$$

Rozważania powyższe są słuszne dla małych wielkości osiadań. Należy zauważyć, że przy ruchu w ośrodku o nie zagęszczonym gruncie, osiadanie jego jest znaczne i objawia się tym, że przed kołem pojazdu tworzy się deformacja w postaci fali o znacznej długości.

\section{Opory ruchu koła na pneumatykach.}

Wielkość oporów ruchu koła na pneumatykach zależy od warunków ich pracy. Jeżeli grunt jest dostatecznie miałki, a sumaryczne ciśnienie wewnętrzne powietrza w pneumatyku koła pi i ciśnienia wynikającego z obliczeń uwzględniających sztywne elementy koła $p_{c}$, które może być większe niż ciśnienie maksymalne, możliwe do przeniesienia przez grunt w najniższym punkcie krzywizny koła. W tej sytuacji koło powodować będzie powstanie krzywizny podobnej jak w przypadku koła sztywnego. Ilustrację tego stanu stanowi rys.2. Z drugiej zaś strony, jeżeli grunt jest dostatecznie wytrzymały, wówczas część krzywizny koła dozna odkształcenia. Przy obliczeniu oporu ruchu koła konieczne jest przyjęcie odpowiedniego założenia, które polega na tym czy koło pracować będzie jak sztywny lub sprężysty okrąg $\mathrm{w}$ danych warunkach eksploatacji.

Jeżeli koło pracuje jako sztywne to, słuszne są założenia teorii [7] między ciśnieniem a osiadaniem. Otrzymuje się wówczas normalne ciśnienie $p_{q}$ w najniższym punkcie kontaktowym w postaci

$$
p_{q}=\left[\frac{k_{c}}{b}+k_{\varphi}\right] z_{o}^{n}
$$


Natural airfield pavements, load-carrying capacities there of, principles of... Naturalne nawierzchnie lotnisk ich nośność oraz warunki budowy i użytkowania

Wykorzystując równanie (11) i zależność (14) otrzymamy

$$
p_{q}=\left[\frac{k_{c}}{b}+k_{\varphi}\right]^{\frac{1}{2 n+1}}\left[\frac{3 W}{(3-n) b \sqrt{D}}\right]^{\frac{2 n}{2 n+1}}
$$

Jeżeli suma ciśnień ciśnienia wewnętrznego w kołach i ciśnienia pc będzie większa niż pq, które można nazwać ciśnieniem maksymalnym $\mathrm{p}_{\mathrm{cr}}$, koło to będzie tworzyć okrągły ślad, tak jak sztywne koło. W tych warunkach opory ruchu w następstwie zagęszczenia gruntu można określić wg równania (12). Z drugiej zaś strony, jeżeli suma $\mathrm{p}_{\mathrm{i}} \mathrm{i} \mathrm{p}_{\mathrm{c}}$ jest mniejsza niż przeprowadzone obliczenia wg zależności (15), to wówczas część otaczająca koło będzie odkształcona i ciśnienie kontaktowe na płaską część będzie sumą ciśnień $\mathrm{p}_{\mathrm{i}} \mathrm{i} \mathrm{p}_{\mathrm{c}}$. Dla tego przypadku osiadanie koła $\mathrm{z}_{\mathrm{o}}$ można określić wg następującej zależności

$$
z_{o}=\left(\frac{p_{i}+p_{c}}{\frac{k_{c}}{b}+k_{\varphi}}\right)^{1 / n}
$$

Zależność ta wykorzystuje związki przedstawione w opracowaniu [7] między ciśnieniem i osiadaniem. Wykorzystując równania (16) i (3) otrzymamy zależność dla obliczenia oporów ruchu sprężystego koła w wyniku konsolidacji gruntu.

$$
R_{c}=b\left(\frac{z_{o}^{n+1}}{n+1}\right)\left(\frac{k_{c}}{b}+k_{\varphi}\right)=\frac{b\left(p_{i}+p_{c}\right)^{\frac{n+1}{n}}}{(n+1)\left(\frac{k_{c}}{b}+k_{\varphi}\right)^{1 / n}}
$$

Dla kół, których szerokość jest dostatecznie duża, konieczne jest wyznaczenie osiadania i oporów ruchu wg zależności (16) i (17). Dla kól, które mają mniejsze wymiary płaszczyzny obciążenia nie jest konieczna duża szerokość koła o długości kontaktowej strefy $1_{t}$, wykazana na rys.2 może być najmniejszym wymiarem. Oznacza to, że dla określenia charakterystyk rozpatrywanych kół środków transportowych na początku ocenić należy długość strefy kontaktu.

$\mathrm{Z}$ dużym przybliżeniem można założyć, że długość strefy kontaktu $1_{\mathrm{t}}$ jest funkcją odkształcenia koła $\delta$ t, co przedstawiono w postaci zależności

$$
l_{t}=2 \sqrt{D \delta_{t}-\delta_{t}^{2}}
$$


Gdy długość kontaktowej strefy $1_{\mathrm{t}}$ jest na ogół mniejsza mniejsza niż szerokość koła. Wyznaczyć można wielkość jej osiadania $\mathrm{z}_{\mathrm{o}} \mathrm{z}$ zależności.

$$
z_{o}=\left(\frac{p_{i}+p_{c}}{\frac{k_{c}}{l_{t}}+k_{\varphi}}\right)^{1 / n}
$$

Pionowe obciążenie $\mathrm{W}$ na koło wyraża ciśnienie na grunt $p_{q}=p_{c}+p_{\mathrm{i}}$ na płaskiej powierzchni AB. Podobnie jak w reakcji na część krzywizny BC. W pierwszym przybliżeniu można przyjąć założenie, że BC jest łukiem krzywizny o promieniu $\mathrm{D} / 2$. Pionowe obciążenie $\mathrm{Wcu}$ oddziaływujące na część $\mathrm{BC}$, można określić w sposób podobny do opisywanego dla przypadku koła sztywnego w punkcie 4.1.

$$
W_{C U}=b\left(\frac{k_{c}}{l_{t}}+k_{\varphi}\right) \sqrt{D} \int_{\sqrt{\delta_{t}}}^{\sqrt{Z_{o}+\delta_{t}}}\left(z_{o}-t^{2}\right)^{n} d t
$$

Rozwijając wyrażenie $\left(\mathrm{z}_{\mathrm{o}}-\mathrm{t}^{2}\right)^{\mathrm{n}}$ i uwzględniając tylko dwa pierwsze człony szeregu, otrzymujemy

$$
W_{C U}=\frac{b\left(\frac{k_{c}}{l_{t}}+k_{\varphi}\right) \sqrt{D}\left(z_{o}+\delta_{t}\right)^{n-1}\left(\sqrt{z_{o}+\delta_{t}}-\sqrt{\delta_{t}}\right)}{3}\left[z_{o}(3-n)+\delta_{t}(3-2 n)-n \sqrt{\delta_{t}\left(z_{o}+\delta_{t}\right)}\right]
$$

W rezultacie, obciążenie pionowe na koło wyniesie

$$
W=b\left(p_{i}+p_{c}\right) l_{t}+W_{C U}
$$

Należy zauważyć, że o pionowym obciążeniu danego koła stanowią następujące parametry $\delta_{\mathrm{t}}, \mathrm{l}_{\mathrm{t}} \mathrm{i} \mathrm{z}_{\mathrm{o}}$. Zależność między $\mathrm{l}_{\mathrm{t}}, \mathrm{z}_{\mathrm{o}} \mathrm{i} \delta_{\mathrm{t}}$ odzwierciedlone $\mathrm{w}$ równaniach (18) i (19). Oznacza to, że dla danych kół ze znanym pionowym obciążeniem mamy określone ugięcia, co przedstawiono w zależności (22) dla określonego rodzaju gruntu. Odkształcenie koła $\delta_{\mathrm{t}}$ można znaleźć obliczając równania (18), (19), (21) i (22). W procesie obliczeń jako pewnej iteracji przyjmujemy założenie i określenie wielkości $\delta_{\mathrm{t}}$. Wykorzystując równanie wyrażające $1_{\mathrm{t}}$ otrzymujemy długość odcinka kontaktowego. Według równania, w którym określamy $\mathrm{z}_{\mathrm{o}}$ oraz znając $\delta_{\mathrm{t}}, 1_{\mathrm{t}}$ można wyznaczyć obciążenie pionowe $\mathrm{W}$, które przejmuje koło. Jeżeli przyjęte znaczenie $\delta_{t}$ jest właściwe, obliczeniowa wielkość $\mathrm{W}$, powinna być równa zadanemu pionowemu obciążeniu. Jeżeli znaczenie $t_{\mathrm{o}}$ jest inne, należy określić nową jego wielkość i prowadzić nową wersję obliczeniową, do czasu uzyskania dostatecznej zgodność. Po określeniu $\delta_{\mathrm{t}}$, obliczeniowe wielkości długości strefy kontaktu $1_{t}$ i osiadania wyznaczonych wg odpowiednich zależności (19) i (20), 
Natural airfield pavements, load-carrying capacities there of, principles of... Naturalne nawierzchnie lotnisk ich nośność oraz warunki budowy i użytkowania

opory ośrodka gruntowego dla koła poruszającego się w nim wyznaczyć można zależności

$$
R_{c}=\frac{b\left(\frac{k_{c}}{l_{t}}+k_{\varphi}\right) z_{o}^{n+1}}{n+1}
$$

Opory pneumatyku mogą być określone w analogiczny sposób jak dla koła sztywnego. Dla kół na pneumatykach występuje rozproszenia energii. Należy pamiętać, że przytoczone wyżej metody odniesione zostały do obliczenia oporów ruchu zagęszczonego gruntu i poruszającego się po nim pojedynczego koła. Własności ośrodka $\mathrm{w}$ kontakcie $\mathrm{z}$ kołami poruszającymi się po śladzie kół poprzedzających., są różne i zależą od własności ośrodka nienaruszonego. Jeżeli ośrodek gruntowy zmienia swoje właściwości pod obciążeniem, to dla określenia charakterystyk drugiej osi układu jezdnego powinny być wykorzystane parametry ośrodka pomierzone na kole. Ustalono, że w ośrodku gruntowym, którego strukturę stanowi luźny piasek, następne przejścia kół powodować będą zwielokrotnienie stopnia deformacji $\mathrm{n}$ powodując pogłębienie się koleiny. Dla gruntów zbudowanych $\mathrm{z}$ wielofrakcyjnych cząstek i określonej strukturze podstawowej, znaczenie współczynnika kg zwykle obniża się w stosunku do obciążenia pierwotnego, wówczas znaczenie n pozostaje stałe lub nieznacznie zwiększa się. W gruntach gliniastych odporność na usuwanie się gruntu może być znacznie zwielokrotniona przy kolejnych przejściach obciążonych kół. Jest oczywiste, że zmiana właściwości ośrodka gruntowego w następstwie przejść kół samolotu lub innych pojazdów zależy przede wszystkim od struktury ośrodka i generowanego obciążenia.

\section{Praktyczne kryteria nośności nawierzchni darniowych}

Kryteria nośności nawierzchni darniowych muszą być powiązane z rodzajem samolotu obliczeniowego, który będzie eksploatowany na danym lotnisku.

W czasie ruchu pojazdu po nawierzchni gruntowej, nawet bez uwzględnienia siły nośnej, oddziaływanie jego na grunt zmienia się wraz ze zmianą prędkości [2]. Grunty odpowiednio zagęszczone wykazują przy krótkotrwałych obciążeniach dynamicznych mniejsze odkształcenia niż w przypadku obciążeń statycznych o tej samej wielkości. Według danych literaturowych [2] i doświadczeń wynikających $\mathrm{z}$ prac nad naprężeniami powstającymi $\mathrm{w}$ gruncie na różnych głębokościach w zależności od prędkości ruchu pojazdu opracowano dane, które przedstawiono w tablicy 4 . W rezultacie tych badań stwierdzono, że wielkości naprężenia powstającego $\mathrm{w}$ gruncie zmniejsza się $\mathrm{w}$ miarę przyrostu prędkości. 
Tablica 4 Zależność pomiędzy naprężeniami w gruncie, a prędkościa ruchu pojazdu

\begin{tabular}{|c|c|}
\hline $\begin{array}{c}\text { Prędkość ruchu } \\
{[\mathrm{km} / \mathrm{h}]}\end{array}$ & Naprężenia na głębokości $25 \mathrm{~cm}$ w MPa \\
\hline 0 & 0,24 \\
\hline 15 & 0,09 \\
\hline 30 & 0,05 \\
\hline 45 & 0,02 \\
\hline
\end{tabular}

Największe oddziaływanie koła samolotu na nawierzchnię występuje w czasie jego postoju. W przypadku postoju samolotu z pracującym silnikiem może nastąpić zjawisko ugrzęźnięcia na skutek wibracji podwozia wywołanej pracą silnika. Schemat naprężeń w gruncie podczas ruchu samolotu przedstawia rysunek 4. Jeżeli przyjmiemy, że nacisk koła na grunt jest równomierny, a kontakt $\mathrm{z}$ podłożem zachodzi na odcinku, to siła wypadkowa $\mathbf{R}$ dzieli ten odcinek na połowę. Tangens kąta pochylenia siły wypadkowej $\mathbf{R}$ wyraża współczynnik tarcia, którego ilustrację przedstawiono na rys. 4.

Czynnikiem decydującym o wielkości odkształcenia gruntu jest jego wytrzymałość. Wytrzymałość gruntu $\sigma$ jest zależna od obciążenia $\mathbf{P}_{\mathbf{k}}$ przypadającego na koło samolotu, od średnicy koła samolotu $\mathbf{D}=\mathbf{2} \mathbf{r}$, i od szerokości koła samolotu B, także od współczynnika sztywności opony $\xi$ oraz od współczynnika m, zależnego od stopnia plastyczności gruntu.

Według [2] wartość $\sigma$ wyraża się wzorem:

$$
\boldsymbol{\sigma}=\frac{\mathrm{q}^{2} \mathrm{~K} \cdot \mathrm{D}}{\mathrm{H} \cdot \mathrm{k}_{\mathrm{H}}}
$$

gdzie: $\mathrm{q}_{\mathrm{k}}=\frac{\mathrm{P}_{\mathrm{K}}}{\mathrm{D} \cdot \mathrm{B}} \quad-$ jest naciskiem na grunt jednego koła podwozia:

- dla głównego podwozia $=0,43 \mathrm{MPa}$,

- dla podwozia dziobowego = 0,44 MPa,

- $\xi$ - sztywność opony

$\mathrm{k}_{\mathrm{H}}=\mathrm{m} \cdot \xi \quad \mathrm{H}-$ głębokość koleiny

Podana w pracy [2] wartość $m$ kształtuje się następująco:

- dla gruntów nasyconych wodą $\mathrm{m}=1,1$

- dla gruntów miękkoplastycznych, $\mathrm{m}=1,2$

- dla gruntów plastycznych, $m=$ od 1,5 do 2,0

- dla gruntów twardoplastycznych, $\mathrm{m}=\mathrm{od} 2,2$ do 2,4 
Natural airfield pavements, load-carrying capacities there of, principles of... Naturalne nawierzchnie lotnisk ich nośność oraz warunki budowy i użytkowania

Po przekształceniu wzoru (24) otrzymujemy wzór na obliczenie głębokość koleiny H:

$$
H=\frac{q^{2} K \cdot D}{\sigma^{2} \cdot k_{H}}
$$

Wartość $\sigma$ wyznacza się w pomiarach poligonowych dla każdego rodzaju gruntu za pomocą sondy udarowej. W badaniach stosuje się najczęściej metodę podaną w pracy [1], która wykorzystuje wyniki badań doświadczalnych. Wartość $\sigma$ przy użyciu sondy udarowej wyznacza się w sposób następujący: określa się najpierw liczbę uderzeń obciążnika przypadających na 10 i $30 \mathrm{~cm}$ zagłębienia sondy w grunt, następnie dla każdej głębokości wnikania sondy ustala się wytrzymałości poszczególne $\sigma_{\mathbf{1 0}}$ i $\boldsymbol{\sigma}_{\mathbf{3 0}}$, a następnie średnią wytrzymałość ze wzoru:

$$
\sigma_{\mathbf{s} \mathbf{r}}=\frac{\sigma_{10}+\sigma_{30}}{2}
$$

W wyniku poruszania się i postoju samolotu obliczeniowego po nawierzchniach darniowych DS nastąpi przemieszczenie gruntu, którego efektem będzie powstanie kolein. Dla określonych wartości $\sigma$ gruntu uzyskanych $\mathrm{z}$ badań poligonowych, określa się przewidywaną głębokość koleiny według wzoru:

$$
\mathrm{H}=\frac{\mathrm{q}_{\mathrm{k}}^{2} \mathrm{D}}{\mathrm{m} \sigma^{2}} \quad \mathrm{q}_{\mathrm{k}}=\frac{\mathrm{P}_{\mathrm{k}}}{\mathrm{DB}}
$$

Jako kryterium właściwej nośności nawierzchni darniowych należy przyjąć maksymalną głębokość koleiny równą 1/14 średnicy koła goleni głównej lub nosowej. Taka wielkość odkształcenia daje przekonanie, że samolot poruszający się po nawierzchni będzie zabezpieczony przed uszkodzeniami spowodowanymi nad-miernym przemieszczeniem podłoża.

Aby doprowadzić do sytuacji, gdzie zagłębienie koła będzie równe $\mathrm{D} / 14$ co na podstawie doświadczeń uważane jest, za zagłębienie umożliwiające bezpieczny ruch samolotów, należy wówczas doprowadzić nawierzchnię gruntową do odpowiedniej wytrzymałości. Inną metodą określania wymaganej wytrzymałości gruntu na podstawie ruchu samolotów po nawierzchniach gruntowych została opracowana przez armię Stanów Zjednoczonych. Do rozwiązania problemu nośności gruntów zastosowano metody kalifornijskiego wskaźnika nośności stosowaną powszechnie przy wymiarowaniu nawierzchni podatnych. Opis metody znajduje się w pracy [3]. Autorzy tej metody uważają, że metoda ta może mieć zastosowanie i do samolotów cięższych.

Za kryterium uszkodzenia względnie zniszczenia nawierzchni przyjęto odkształcenia powstałe pod wpływem ruchu samolotu, który w trakcie operacji miał trudności w manewrowaniu. Ogólnie biorąc, odkształcenia gruntu dzielą się na odkształcenia zanikające, wynoszące od $0,75 \mathrm{~cm}$ do $1,8 \mathrm{~cm}$ i trwałe od $5,0 \mathrm{~cm}$ 
do 10,0 cm. Celem tych badań było opracowanie krzywych CBR dla nawierzchni gruntowych $\mathrm{w}$ zależności od liczby przeprowadzonych operacji od 1-100, dla różnych typów samolotów o podwoziu z pojedynczymi kołami i podwoziu wielokołowym. Wyniki tych badań ilustruje rysunek 6 . Krzywe te służą do oceny gruntu i powstały z krzywych projektowania CBR dla podłoża gruntowego bez nawierzchni sztucznych lub pokrytych powłoką membranową przeciwwilgociową dla lotnisk o krótkotrwałym okresie użytkowania tj. do 40 operacji lotniczych.

Punktem wyjścia do opracowania powyższych wykresów były krzywe ustalania CBR dla nawierzchni podatnych zawarte $\mathrm{w}$ opracowaniu [5]. Wartości te dla samolotów o podwoziu wielokołowym są w przybliżeniu większe o około $20 \%$ w stosunku do wymagań dla samolotów o podwoziu z kołem pojedynczym. Dla projektowania i kontroli stanu nawierzchni gruntowych można posługiwać się metodą badania modułu odkształcenia, dla której przyjmuje się zależność przybliżoną Eo $=10{ }^{\circ} \mathrm{CBR}[\mathrm{MPa}] . \mathrm{W}$ praktyce wartości te wynoszą od 10 do $30 \mathrm{CBR}$.

\section{Użytkowanie nawierzchni darniowej}

Racjonalną zasadą, która powinna być stosowana podczas eksploatacji lotniska o nawierzchni darniowej jest jego podział o ile to możliwe na dwa lub trzy pasy wzlotów. Pasy te sytuuje się najczęściej równolegle do nawierzchni drogi startowej o nawierzchni sztucznej (o ile taka istnieje). Jeden $\mathrm{z}$ wydzielonych pasów (sektorów ruchu) jest użytkowany, pozostałe są w renowacji. Szerokość tych pasów wynosi około $60 \mathrm{~m}$. Na zewnętrznych granicach tego pasa (strefy) wzlotów umieszcza się stosowne znaki zapewniające bezpieczeństwo ruchu lotniczego. Okres użytkowania sektora nawierzchni wydzielonego do ruchu zależy od: intensywności startów i lądowań samolotów, mechanicznych własności gleby i jakości darni. W przeciętnych warunkach pogodowych nie przekracza się zazwyczaj 10-15 dni eksploatacji. Należy zaniechać użytkowania nawierzchni (określonych stref-wynikających $\mathrm{z}$ wcześniejszego podziału), jeżeli stopień przydatności darni wynosi 20 - 30 \%. Użytkowanie jej można wznowić wówczas, gdy po wykonaniu niezbędnych zabiegów regeneracyjnych trawa odrośnie do wysokości $10-15 \mathrm{~cm}$, na co w przeciętnych warunkach klimatycznych naszego kraju potrzeba około 1,5 do 2 miesięcy.

Ustalając racjonalne zasady eksploatacji nawierzchni i zapobiegając jej przedwczesnemu zniszczeniu, zaleca się kontynuować starty w okresie 5 - 7 dni w tej samej wydzielonej strefie nawierzchni. Zmiana pasa wzlotów zależy przede wszystkim - od liczby startów i lądowań, stanu darni, a także jej własności i rodzaju gleby, typu samolotu, który eksploatowany jest na danym lotnisku i generuje najbardziej niekorzystne obciążenie. Zasadniczymi kryteriami, których spełnieniem należy się kierować przy projektowaniu, budowie, czy procesach związanych z utrzymaniem nawierzchni, są:

a) kryterium głębokości koleiny,

b) kryterium określone wg wskaźnika CBR,

c) wytrzymałość średnia $\sigma_{\mathrm{Sr}}$ nawierzchni,

d) stopień zwięzłości darni. 
Natural airfield pavements, load-carrying capacities there of, principles of... Naturalne nawierzchnie lotnisk ich nośność oraz warunki budowy i użytkowania

Kryteria wymienione w pkt. a i b przedstawiono w pkt 4. opracowania. Autorzy pracy [4] uzasadnili racjonalność stosowania wymienionych wyżej kryteriów. Można przewidywać głębokość koleiny, która powstanie podczas operacji lotniczej. Przewidywaną jej głębokość można wyznaczyć graficznie z wykresu, posługując się średnią wytrzymałością gruntu $\sigma_{s \mathrm{~s}}$. Wytrzymałość średnia oznacza wynik uzyskany $\mathrm{z}$ trzech pomiarów na stanowisku badawczym nawierzchni darniowej, którą wyraża zależność:

$$
\sigma_{\mathbf{s} \mathbf{r}}=\left[\frac{\sigma_{10(1)}+\sigma_{30(1)}}{2}+\frac{\sigma_{10(2)}+\sigma_{30(2)}}{2}+\frac{\sigma_{10(3)}+\sigma_{30(3)}}{2}\right]: \mathbf{3}
$$

gdzie: $\sigma_{10}, \sigma_{30}$ - są wytrzymałością warstwy nawierzchni gruntowej na głębokości 10 i $30 \mathrm{~cm}$.

Wskaźniki $(1,2,3)$ oznaczają kolejność badań sondą udarową na stanowisku badawczym. Koniecznym warunkiem uzyskania dobrej nawierzchni jest spełnienie następującej nierówności: $\boldsymbol{\sigma}_{\mathbf{1 0}} \leq \boldsymbol{\sigma}_{30}$.

Wymaga się by wytrzymałość średnia uzyskana na stanowisku badawczym była nie mniejsza niż 0,8 MPa. Zwięzłość darni jest kategorią subiektywną i są jej trzy rodzaje tj. mało zwięzła, średnio i silnie zwięzła. Dla przykładu stan darni silnie zwięzłej określa się następująco: jest to nawierzchnia, która z dużym trudem daje się rozerwać rękami, łatwiej zaś sztychówką lub motyką.

Przydatność eksploatacyjna lotnisk o nawierzchni darniowej uwarunkowana jest przede wszystkim dobrym wyrównaniem terenu i silnym zadarnieniem nawierzchni. Darń nawierzchni lotniska tworzą poprzerastane nawzajem kępy, korzenie, rozłogi traw i roślin motylkowych. Prace konserwacyjne związane $\mathrm{z}$ utrzymaniem tego rodzaju nawierzchni na lotniskach mają na celu przygotowanie dla roślin odpowiednich warunków rozwoju. Wymienić tu należy również: prowadzenie drobnych prac porządkowych i ziemnych, likwidacja nierówności, zbieranie kamieni itp.

Nawierzchnia lotniskowa trawiasta jest nawierzchnią złożoną $\mathrm{z}$ roślin, które rozrastając się i rozkrzewiając wzmacniają warstwę nośną i udoskonalają ja pod względem głównie wytrzymałościowym. Eksploatatorzy takich nawierzchni powinni stworzyć takie warunki środowiskowe, które byłyby korzystne z punktu rozwoju roślin i eliminowałyby czynniki szkodliwe. Rozwój roślinności darniowych nawierzchni lotniskowej podyktowany jest:

a) warunkami klimatycznymi: temperatura powietrza, światłem, ilością opadów,

b) własnościami fizycznymi i chemicznymi gleby, przede wszystkim jej strukturą, poziomem wody gruntowej, retencyjnością gleby, zasobnością w składniki pokarmowe,

c) wpływem świata zwierzęcego. 
Do zasadniczych przedsięwzięć utrzymaniowych na nawierzchniach trawiastych należą:

- likwidacja nierówności i inne prace porządkowe,

- konserwacja urządzeń wodnych,

- nawożenie gleby.

Każde $\mathrm{z}$ tych przedsięwzięć ma swoje określone procedury, gdyż obejmuje kompleks zagadnień, których znaczenie w procesie utrzymania nawierzchni jest istotne.

\section{Podsumowanie}

Przedstawione w publikacji zagadnienia wykazały, że wymagania w stosunku do nawierzchni darniowych i gruntowych lotnisk eksploatowanych przez statki powietrzne są i musza być wysokie. Wymagania dotyczące nawierzchni darniowych i gruntowych mogą być spełnione tylko wówczas, gdy w wyborze miejsca pod przyszłe lotnisko uwzględni się przede wszystkim rodzaj gleby. Nie na wszystkich rodzajach gleby, możliwe będzie utrzymanie nawierzchni we właściwym stanie technicznym, nawet wówczas gdy nakłady związane $\mathrm{z}$ ich utrzymaniem będą znaczne. Nawierzchnie darniowe są w istocie ulepszonym rodzajem nawierzchni gruntowej. Jest oczywiste, że wykorzystanie tych nawierzchni przez współczesne samoloty wiąże się ze znacznymi ograniczeniami, do których należą: pora roku, ciężar startowy oraz rodzaj podwozia samolotu i inne. Stan techniczny tych nawierzchni, uzależniony jest przede wszystkim od zapewnienia odpowiednich stosunków gruntowo - wodnych na obiekcie i w jego rejonie. W publikacji wyróżniono najbardziej przydatne do celów lokalizacji lotniska rodzaje gleb. Podstawowe zalety, którymi charakteryzują się nawierzchnie trawiaste i gruntowe są następujące: odpowiednia podatność nawierzchni pokrytej runią roślinną, która minimalizuje skutki dynamicznego lądowania, stosunkowo duży współczynnik sczepności koła samolotu z warstwą zadarnioną nawierzchni wpływa na skrócenie drogi i czasu lądowania samolotu, niewielkie zużycie opon przy wykonywaniu operacji startów i lądowań. Zasadnicze ograniczenia w wykorzystaniu nawierzchni lotniskowych trawiastych i gruntowych dotyczą: sezonowości wykorzystania lotniska i w porównaniu z nawierzchniami sztucznymi mniejsza ich nośnością, uzyskanie darni o odpowiedniej nośności i walorach eksploatacyjnych wymaga stosunkowo dhugiego czasu, regeneracja nawierzchni trawiastych i gruntowych jest również procesem długotrwałym. Reasumując nawierzchnie trawiaste $i$ gruntowe mogą być eksploatowane przez samoloty lżejsze w zasadzie bez ograniczeń. Dla samolotów cięższych, komunikacyjnych nawierzchnie tych lotnisk stawiają ograniczenia. Uciążliwość tych ograniczeń można minimalizować przez konsekwentne przestrzeganie procedur utrzymaniowych. Lotniska mające ten rodzaj nawierzchni mają obecnie szansę rozwoju w związku zapotrzebowaniem na lotnictwo indywidualne i dyspozytorskie, będzie to jednak zawsze lotnictwo uzupełniające i taki charakter będą miały lotniska posiadające ten rodzaj nawierzchni. Przydatność tych lotnisk do celów sportowych nigdy nie była kwestionowana. 
Natural airfield pavements, load-carrying capacities there of, principles of... Naturalne nawierzchnie lotnisk ich nośność oraz warunki budowy i użytkowania

\section{Literatura}

[1] E. Karneński Nośność lotniskowych nawierzchni darniowych. Instytut Techniczny Wojsk Lotniczych. Warszawa 1967.

[2] W.F. Babkow, A.S. Smirnow: Opriedielenie procznosti grunta dla projezda kolesnych maszin. Proceedings of the International Conference on Soil Mechanics and Foundation Engineering. Akademia Kiadó Budapest 1963.

[3] W.J. Turnbull, A.A. Maxwell, C.O. Burnus: Strenght Requirements in Unsurfaced Soils for Aircraft Operations, Proceedings of Fifth International Conference on Soil Mechanics and Foundation Engineering. Dunod. Paris 1961.

[4] M. Graczyk, P. Nita: Poprawa nośności nawierzchni poboczy gruntowych dróg startowych, kryteria i ocena nośności. Instytut Techniczny Wojsk Lotniczych. Warszawa 1996.

[5] Enginering and Design, Flexible Airfield Pavements, Air Force, E.M. 111045-302. Washington D.C. 1958.

[6] Wong J. Y.: Behaviur of Soil Beneath Rigid Wheels, Journal of Agricultural Enginering Resarch, Vol.12, No.4, 1967

[7] Bekker M.G.: Theory of Land Locomotion by the Universtity of Michigan 1956

[8] Uffelman F.L.: The Performance of Rigid Cylindrical Wheels on Clay Soils. Proceedingsof the First International Conference on Soil Vehicle Mechanics, Turyn, Italy, 1961

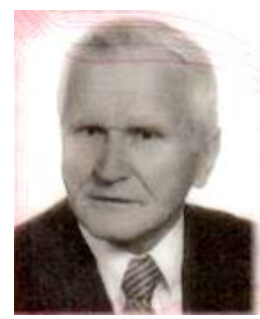

prof. dr. hab. inz. Piotr Nita jest dlugoletnim pracownikiem Instytutu Technicznego Wojsk Lotniczych, Jego zainteresowania naukowe $i$ zawodowe dotycza budownictwa komunikacyjnego a przede wszystkim; projektowania lotnisk $i$ portów lotniczych, budowy nawierzchni lotniskowych i procesów ich utrzymania. Jest autorem kilku publikacji ksiażkowych dotyczacych tej dziedziny inżynierii ladowej $i$ wielu specjalistycznych artykutów opublikowanych $w$ krajowej i zagranicznej literaturze technicznej oraz referatów przedstawianych na konferencjach naukowych krajowych i zagranicznych. 